\title{
Antioxidant effects of pineapple vinegar in reversing of paracetamol-induced liver damage in mice
}

Nurul Elyani Mohamad', Swee Keong Yeap ${ }^{2}$, Kian Lam Lim³, Hamidah Mohd Yusof ${ }^{3}$, Boon Kee Beh³, Sheau Wei Tan², Wan Yong Ho ${ }^{4}$, Shaiful Adzni Sharifuddin ${ }^{5}$, Anisah Jamaluddin ${ }^{5}$, Kamariah Long ${ }^{5}$, Nik Mohd Afizan Nik Abd Rahman ${ }^{1}$ and Noorjahan Banu Alitheen ${ }^{1 *}$

\begin{abstract}
Background: Pineapple (Ananas comosus) was demonstrated to be hepatoprotective. This study aims to investigate the reversing effects of pineapple vinegar on paracetamol-induced liver damage in murine model.

Methods: Pineapple juice was fermented via anaerobic and aerobic fermentation to produce pineapple vinegar. Male BALB/C mice $(n=70)$ were separated into 7 treatment groups $(n=10)$. Pineapple vinegar $(0.08$ and $2 \mathrm{~mL} / \mathrm{kg} \mathrm{BW})$ and synthetic vinegar were used to treat paracetamol-induced liver damage in mice. The hepatoprotective effects were determined by serum biochemistry profiles (aspartate aminotransferase (AST), alanine aminotransferase (ALT), alkaline phosphatase (ALP), and triglyceride (TG)), liver antioxidant levels (ferric-reducing ability plasma (FRAP), superoxide dismutase (SOD), malondialdehyde (MDA), nitric oxide (NO), and reduced glutathione assays (GSH)) and histopathological examination with hematoxylin and eosin (H\&E) staining. The effects were further evaluated by the expression levels of iNOS, NF-KB, and cytochrome P450 2E1 by quantitative real-time PCR and Western blot analyses. Vinegar samples were also tested for in vitro antioxidant (FRAP, 2,2-diphenyl-2-picrylhydrazyl (DPPH), and total phenolic content (TPC)). Soluble phenolic acid contents in the samples were identified by HPLC.

Results: Pineapple vinegar contained $169.67 \pm 0.05 \mu \mathrm{g} \mathrm{GAE} / \mathrm{mL}$ of TPC, with $862.61 \pm 4.38 \mu \mathrm{g} / \mathrm{mL}$ gallic acid as the main component. Oral administration of pineapple vinegar at $2 \mathrm{~mL} / \mathrm{kg}$ BW reduced serum enzyme biomarker levels, including AST $(P=0.008)$, ALT $(P=0.006)$, ALP $(P=0.002)$, and TG $(P=0.006)$ after 7 days of paracetamol treatment. Liver antioxidant levels such as hepatic glutathione $(P=0.003)$, SOD $(P<0.001)$, lipid peroxidation $(P=0.002)$ and FRAP $(P<0.001)$ were restored after the treatment. Pineapple vinegar reduced the expressions of iNOS $(P=0.003)$ and NF-kB $(P=0.003)$ and the level of NO $(P=0.003)$ significantly. Pineapple vinegar also downregulated liver cytochrome $P 450$ protein expression.

Conclusions: Oral administration of pineapple vinegar at 0.08 and $2 \mathrm{~mL} / \mathrm{kg}$ BW reduced serum enzyme biomarker levels, restored liver antioxidant levels, reduced inflammatory factor expressions, and down regulated liver cytochrome P450 protein expression in paracetamol-induced liver damage in mice.
\end{abstract}

\footnotetext{
* Correspondence: noorjahan@upm.edu.my

'Department of Cell and Molecular Biology, Faculty of Biotechnology and Biomolecular Science, Universiti Putra Malaysia, Serdang, Selangor 43400, Malaysia

Full list of author information is available at the end of the article
} 


\section{Background}

The functions of the liver, such as fatty acid metabolism [1], protein synthesis [2], and detoxification [3], would be impaired by excessive intake of ethanol, carbon tetrachloride $\left(\mathrm{CCl}_{4}\right)$, and iron, causing accumulation of free radicals in the body [4]. Over-consumption of paracetamol causes hepatic necrosis and inflammation through activation of cytochrome $\mathrm{P} 450$ by $\mathrm{N}$-acetyl-pbenzoquinoneimine (NAPQI) in paracetamol [5,6]. During the process, reactive oxygen species (ROS) are produced excessively [7]. Fruits are rich in antioxidant compounds that may help protect the body against ROS-mediated damage [8]. Vinegar produced from fruits enhanced the reduced glutathione (GSH) antioxidant system and scavenged the radical activities, thereby protecting the liver cells from damage [9].

Vinegar produced from carbohydrate sources, such as fruits and grains, contains not only acetic acid, but also other bioactive compounds such as polyphenolics, volatile compounds, and organic acids [10]. Production of vinegar involves alcoholic and acetic fermentations. Yeast converts sugar into alcohol during alcoholic fermentation, which is then transformed into acetic acid by Acetobacter bacteria during acetic fermentation [10]. Many studies have evaluated the functionality and pharmacological effects of vinegar in treating and preventing certain diseases such as hypercholesterolemia [11], hyperglycemia [12], hypertension [13], and cancer [14]. Vinegar also possessed an anti-thrombotic effect [15] and antimicrobial activity [16]. Vinegar produced from Hovenia dulcis peduncles shows a hepatoprotective effect against alcoholinduced liver damage in mice [17].

Pineapple (Ananas comosus) is one of the carbohydrate sources for vinegar production. It is commonly grown in tropical and subtropical countries, including Hawaii, India, China, Kenya, South Africa, Malaysia, Philippines, and Thailand [18]. Pineapple contains phenolic compounds, vitamins, and several proteinases such as bromelain, comosain, and ananain, which are antioxidants [19]. According to the literature, pineapple protects the liver intoxicated by paracetamol-induced damages in rats [20,21]. However, there have been no scientific reports on the effects of pineapple vinegar on paracetamol-induced hepatotoxicity.

This study aims to investigate the hepatoprotective effects of pineapple vinegar on paracetamol-induced liver damage in male BALB/c mice.

\section{Methods}

\section{Chemicals and samples}

Folin-Ciocalteu reagent, 2,2-diphenyl-2-picrylhydrazyl (DPPH), 2,4,6-tripyridyl-s-triazine (TPTZ), $\mathrm{FeCl}_{3} \cdot 6 \mathrm{H}_{2} \mathrm{O}$, gallic acid, and trolox were purchased from Sigma (USA). Silybin was purchased from BiO-LiFE (Malaysia). Saccharomyces cerevisiae 7013 INRA and Acetobacter acetii var. Europeans used in the production of vinegar were obtained from the culture collection center of the Malaysian Agriculture and Research Development Institute (MARDI), Malaysia.

A vinegar sample was made from pineapple fruit obtained from a local market (Pasar Borong Selangor, Selangor). Briefly, the pineapple fruits were sliced and blended to produce the juice. The juice was inoculated with S. cerevisiae 7013 INRA for 7-10 days under anaerobic fermentation at $28-30^{\circ} \mathrm{C}$ to produce alcohol, and then further inoculated with Acetobacter acetii vat Europeans to allow aerobic fermentation to occur at $28-30^{\circ} \mathrm{C}$. After 4 weeks of incubation, $6-8 \%$ acetic acid was produced and the solution was transferred to a storage tank for 1 month for the maturation process. Finally, the vinegar product was filtered, placed in a glass bottle (Schott, Germany), and stored at $4^{\circ} \mathrm{C}$. Samples for this study were freshly prepared daily by dilution of the vinegar product with distilled water.

\section{Animals}

Male BALB/c mice (4-5 weeks of age) with an average weight of 20-22 g were obtained from the Animal House of the Faculty of Veterinary Sciences, Universiti Putra Malaysia. The mice were placed in plastic cages at room temperature $\left(21-23^{\circ} \mathrm{C}\right)$ with a $12-\mathrm{h} / 12$-h dark/light cycle and relative humidity of approximately $60 \%$. They received a standard pellet diet and distilled water ad libitum and were acclimatized for 7 days prior to the experiment. This study was approved by the Animal Care and Use Committee, Universiti Putra Malaysia (UPM/ FPV/PS/3.2.1.551/AUP-R168), and conducted according to the guidelines from the committee.

\section{Experimental design}

The mice were arbitrarily divided into seven groups with ten mice each. The treatment was performed according to a previous study with slight modifications [22]. The high-dose vinegar group was designed according to a previous in vivo study with a vinegar sample [23], while the low-dose vinegar group was modified to reduce the dose and make it equivalent to the concentration of one tablespoon of vinegar in a $250 \mathrm{~mL}$ glass of water. All groups, except for the normal control group (group 1), were treated with paracetamol at $250-\mathrm{mg} / \mathrm{kg}$ body weight $(\mathrm{BW})$ to induce liver damage in mice via oral gavage for 7 days. After 7 days, all mice were subjected to oral treatments once daily for 14 days via oral gavage as follows:

Group 1: normal control group without paracetamol induction receiving distilled water only;

Group 2: untreated paracetamol control group receiving distilled water only;

Group 3: positive control group receiving $50-\mathrm{mg} / \mathrm{kg}$ $\mathrm{BW}$ of silybin; 
Group 4: acetic acid control group receiving 2-mL/kg BW of synthetic vinegar;

Group 5: acetic acid control group receiving $0.08-\mathrm{mL} / \mathrm{kg} \mathrm{BW}$ of synthetic vinegar;

Group 6: treatment group receiving $2 \mathrm{~mL} / \mathrm{kg}-\mathrm{BW}$ of pineapple vinegar; and

Group 7: treatment group receiving $0.08-\mathrm{mL} / \mathrm{kg}$ BW of pineapple vinegar.

At the end of the experimental period, all mice were anesthetized with isoflurane, and euthanized by cervical dislocation. Liver and serum were collected and subjected to the following assays.

\section{Serum biomarker assays}

Sera were collected for quantification of the following enzyme markers: aspartate aminotransferase (AST), alanine aminotransferase (ALT), alkaline phosphatase (ALP), and triglyceride (TG). The assays were performed in a biochemical analyzer (Hitachi 902 Automatic Analyzer; Hitachi, Japan) with adapted reagents from Roche (Germany).

\section{Liver antioxidant levels}

The liver was excised from each mouse, washed with ice-cold phosphate buffer $(137-\mathrm{mM} \mathrm{NaCl}, 2.7-\mathrm{mM} \mathrm{KCl}$, 10-mM Na${ }_{2} \mathrm{HPO}_{4}, 2-\mathrm{mM} \mathrm{KH}_{2} \mathrm{PO}_{4}, \mathrm{pH} 7.4$ ), and weighed before being divided into several parts. One part of the liver was mashed using a $0.2-\mu \mathrm{m}$ cell strainer (SPL Life Sciences, China) and syringe rubber plunger in cold phosphate-buffered saline (PBS) to obtain a liver homogenate. The liver homogenate was used to determine the levels of ferric-reducing ability plasma (FRAP), superoxide dismutase (SOD), malondialdehyde (MDA), and nitric oxide (NO) according to previously described methods [24], while the GSH levels were determined with a Glutathione Assay Kit (Sigma-Aldrich, USA).

\section{FRAP assay}

A master solution was prepared by mixing $30 \mathrm{~mL}$ of 300-mM acetate buffer with $3 \mathrm{~mL}$ of $10-\mathrm{mM}$ TPTZ solution and $3 \mathrm{~mL}$ of $20-\mathrm{mM} \mathrm{FeCl} 3 \cdot 6 \mathrm{H}_{2} \mathrm{O}$ solution in 40-mM HCl. The solution was kept in the dark at $37^{\circ} \mathrm{C}$. For the assay, $80 \mu \mathrm{L}$ of liver homogenate and $150 \mu \mathrm{L}$ of master solution were added to a 96 well-plate and mixed thoroughly. After $10 \mathrm{~min}$ of incubation, the absorbances were measured at $593 \mathrm{~nm}$ in an ELISA Plate Reader (Bio-Tek Instruments, USA) and the activity was calculated from a standard $\mathrm{FeSO}_{4}$ calibration curve.

\section{SOD assay}

A master solution was prepared by adding $0.1-\mathrm{mol} / \mathrm{L}$ phosphate buffer, $0.15-\mathrm{mg} / \mathrm{mL}$ sodium cyanide in $0.1-\mathrm{mol} / \mathrm{L}$ ethylenediaminetetraacetic acid (EDTA), $1.5-\mathrm{mmol} / \mathrm{L}$ nitroblue tetrazolium, and $0.12-\mathrm{mmol} / \mathrm{L}$ riboflavin. In brief,
$100 \mu \mathrm{L}$ of a serial dilution of liver homogenates were pipetted into a 96-well plate and mixed well with $200 \mu \mathrm{L}$ of master solution. The absorbances were then measured at $560 \mathrm{~nm}$ using ELISA Plate Reader (Bio-Tek Instruments, USA) and the activity was expressed as units SOD/mg protein.

\section{MDA assay}

Each liver homogenate $(200 \mu \mathrm{L})$ was diluted with $800 \mu \mathrm{L}$ of PBS and mixed with $25 \mu \mathrm{L}$ of $8.8 \mathrm{mg} / \mathrm{mL}$ butyhydroxytoluene and $500 \mu \mathrm{L}$ of $50 \%$ trichloroacetic acid. The mixture was vortexed, incubated for $2 \mathrm{~h}$ on ice, and centrifuged (MX-160 Tomy, Japan) at $2000 \times g$ for $15 \mathrm{~min}$. The supernatant $(1 \mathrm{~mL})$ was transferred into a new tube and mixed with $75 \mu \mathrm{L}$ of $0.1-\mathrm{M}$ EDTA and $250 \mu \mathrm{L}$ of $0.05-\mathrm{M}$ 2-thiobarbituric acid. The mixture was boiled for $15 \mathrm{~min}$ and allowed to cool to room temperature before the absorbances were measured at 532 and $600 \mathrm{~nm}$ in an ELISA Plate Reader (Bio-Tek Instruments, USA).

\section{NO assay}

NO activity was determined using a Griess reagent kit (Invitrogen, USA) according to the manufacturer's protocol. Griess reagent $(20 \mu \mathrm{L})$ was mixed with $150 \mu \mathrm{L}$ of liver homogenate and $130 \mu \mathrm{L}$ of distilled water in a 96 well-plate and incubated for $30 \mathrm{~min}$ at room temperature. The absorbances were measured at $540 \mathrm{~nm}$ in an ELISA Plate Reader (Bio-Tek Instruments, USA).

\section{GSH activity assay}

The GSH level was determined using a Glutathione Assay Kit (Sigma-Aldrich, USA). Briefly, $10 \mathrm{~mL}$ of liver homogenate and $150 \mu \mathrm{L}$ of working solution $(1.5 \mathrm{mg} / \mathrm{mL}$ DTNB, $6 \mathrm{U} / \mathrm{mL}$ glutathione reductase, and $1 \times$ assay buffer) were added to a 96 well-plate and mixed thoroughly. The plate was incubated for $5 \mathrm{~min}$ before $50 \mathrm{~mL}$ of NADPH solution $(0.16 \mathrm{mg} / \mathrm{mL})$ was added to each well. The absorbances were measured at $412 \mathrm{~nm}$ in an ELISA Plate Reader (Bio-Tek Instruments, USA) at 1-min intervals for $5 \mathrm{~min}$.

\section{RNA isolation and quantitative real-time PCR gene expression analysis}

Livers were stored in RNAlater solution (Life Technologies, USA) to preserve the RNA. The RNA was then extracted using an RNeasy Mini Kit (Qiagen, Germany). Total RNA $(1 \mu \mathrm{g})$ was reverse-transcribed to first-strand cDNA using iScript $^{\mathrm{Tm}}$ Reverse Transcription Supermix for RT-qPCR (Bio-Rad, USA) according to the manufacturer's protocols. Quantitative real-time PCR was performed with iTaq $^{\text {mm }}$ Universal SYBR ${ }^{\odot}$ Green Supermix (Bio-Rad, USA). The following primers were used: nuclear factor kappalight-chain-enhancer of activated B cells (NF-kB): forward 5'-CATTCTGACCTTGCCTATCT-3' and reverse 
3'-CTGCTGTTCTGTCCATTCT-5'; inducible nitric oxide synthase (iNOS): forward 5'-GCACCGAGATTG GAGTTC-3' and reverse 3'-GAGCACAGCCACATT GAT-5'; beta-actin (ACTB): forward 5'-TTCCAGCCTTC CTTCTTG-3' and reverse 3'-GGAGCCAGAGCAGTA ATC-5'; hypoxanthine phosphoribosyl transferase (HPRT): forward 5'-CGTGATTAGCGATGATGAAC-3' and reverse 3'-AATGTAATCCAGCAGGTCAG-5'; and glyceraldehyde 3-phosphate dehydrogenase (GAPDH): forward 5'-GAAGG TGGTGAAGCAGGCATC-3' and reverse 3'-GAAGGTG GAAGAGTGGGAGTT-5'. The quantities of the target genes and the housekeeping genes ACTB, HPRT, and GAPDH were calculated according to a standard curve and the expressions of NF-kB and iNOS were measured using CFX Manager Software (Bio-Rad, USA). The expression levels in all samples were compared with those in the untreated control group, and the levels of the different mRNAs in the untreated control group were designated as 1. All results were expressed as fold changes and measured in triplicate. Non-template controls were used to confirm specificity.

\section{Western blotting}

P450 protein expression levels were determined by Western blotting [25] with beta-actin (ab8227; Abcam, USA) as a housekeeping control. Briefly, total protein was extracted from $30 \mathrm{mg}$ of fresh liver tissues using RIPA buffer (50-mM Tris $\mathrm{pH} 8,150-\mathrm{mM} \mathrm{NaCl}, 1 \%$ Triton X-100, $0.1 \%$ sodium deoxycholate, $0.1 \%$ SDS) supplemented with a phosphatase inhibitor cocktail (Roche, Canada). Next, aliquots containing $100 \mu \mathrm{g}$ of protein were separated by $10 \%$ sodium dodecyl sulfate-polyacrylamide gel electrophoresis and transferred to a nitrocellulose membrane (Roche, Canada) using a Pierce Fast Semi-Dry Blotter (Pierce, USA). The membrane was blocked with $1 \%$ skimmed milk for $2 \mathrm{~h}$, washed with TBST buffer (1.5-M NaCl, 0.5-M Tris, $\mathrm{pH}$ 7.5) three times, and incubated with an anti-cytochrome P450 2E1 antibody (ab28146; Abcam, USA). Next, the membrane was incubated with a secondary antibody conjugated with horseradish peroxidase (Abcam, USA). The chemiluminescence signals (Super Signal West Pico; Pierce, USA) were developed using a Chemi Doc UVP machine (UVP, USA). The density results were analyzed using Vision Work LS Analysis software (UVP, USA).

\section{Histopathology}

One part of the fresh liver tissues was placed in plastic cassettes and immersed in neutral-buffered formalin for $24 \mathrm{~h}$ [26]. The fixed tissues were embedded in paraffin, sectioned, deparaffinized, rehydrated using standard techniques, and stained with hematoxylin and eosin. The stained liver sections were observed under a Nikon Eclipse 90i microscope (Nikon, USA) using bright-field optics at $40 \times$ magnification.

\section{Determination of total phenolic contents and soluble phenolic acid compounds}

The total phenolic contents of vinegar samples were determined by the Folin-Ciocalteu assay and the results were expressed in milligrams of gallic acid [27]. Briefly, samples were incubated with Folin-Ciocalteu reagent (Sigma, USA) for 3-8 min. The mixture was then added with $0.8 \mathrm{~mL}$ of $7.8 \%$ sodium carbonate (Sigma, USA) solution and incubated at room temperature for $2 \mathrm{~h}$. The absorbances were measured at $765 \mathrm{~nm}$ in an ELISA Plate Reader (Bio-Tek Instruments, USA).

Free phenolic acids in vinegar samples were quantified using an HPLC Alliance Separation Module (Waters, USA) equipped with a diode array detector as described in [28] with slight modifications. Briefly, undiluted $10-\mu \mathrm{L}$ samples were injected into a reverse-phase analytical column $(150 \mathrm{~mm} \times 4.6 \mathrm{~mm} \times$ Bridge $\mathrm{C} 18,3.5 \mu \mathrm{m}$; Waters, USA) at a controlled temperature of $25^{\circ} \mathrm{C}$ for separation. The mobile phase was $0.1 \%$ formic acid and methanol with a flow rate of $0.7 \mathrm{~mL} / \mathrm{min}$. The data obtained were analyzed against corresponding standards (gallic acid, protocatechuic acid, $\beta$-hydroxybenzoic acid, vanillic acid, caffeic acid, syringic acid, sinapic acid, and benzoic acid).

\section{In vitro evaluation of antioxidant activities of vinegar samples \\ DPPH assay}

The free-radical-scavenging activities of the vinegar samples were measured by the DPPH assay with trolox as the standard [29]. Briefly, $50 \mu \mathrm{L}$ of pineapple vinegar and synthetic vinegar were added to $250 \mu \mathrm{L}$ of DPPH working solution and incubated in the dark for $30 \mathrm{~min}$. The absorbances were measured in an ELISA Plate Reader (Bio-Tek Instruments, USA).

\section{FRAP assay}

The FRAP assay was performed according to Thaipong et al. [29] with slight modifications. A working solution was prepared by adding $4 \mathrm{~mL}$ of TPTZ and $4 \mathrm{~mL}$ of $\mathrm{FeCl}_{3} \cdot 6 \mathrm{H}_{2} \mathrm{O}$ to $40 \mathrm{~mL}$ of acetate buffer. The solution was kept at $37^{\circ} \mathrm{C}$ in the dark. For the assay, $20-\mu \mathrm{L}$ aliquots of samples were added to $150 \mu \mathrm{L}$ of FRAP working solution and incubated for $10 \mathrm{~min}$. The absorbances were measured at $593 \mathrm{~nm}$ in an ELISA Plate Reader (Bio-Tek Instruments, USA). The results were calculated from a standard $\mathrm{FeSO}_{4}$ calibration curve and expressed in $\mu \mathrm{M} \mathrm{Fe}^{2+}$.

\section{Statistical analysis}

All assays were repeated in three independent experiments. Means \pm standard deviations (SD) were compared for each group by one-way analysis of variance (ANOVA) and Duncan's multiple range test using SPSS 16.0 statistical software (IBM, USA). $P$ values $<0.05$ were considered 
statistically significant. Dose-dependent manner was visually determined by observing the trend of the data.

\section{Results}

Serum biochemistry

The effects of silybin, synthetic vinegar, and pineapple vinegar on serum biomarkers in paracetamol-treated mice are summarized in Table 1. The levels of ALT, ALP, AST, and TG in the paracetamol-untreated control group were elevated by $2,1.2,2.5$, and 1.5 -fold $\left[P_{A L T}=0.033\right.$, $\left.P_{A L P}=0.023, P_{A S T}=0.020, P_{T G}=0.022\right]$, respectively, compared with the normal control group. The elevations of these marker enzymes indicated hepatic injury and loss of structural integrity in liver cells. Treatments with silybin $\left[P_{A L T}=0.003, P_{A L P}=0.003, P_{A S T}=0.002, P_{T G}=0.010\right]$ synthetic vinegar $\left[P_{A L T}=0.010, P_{A L P}=0.003, P_{A S T}=0.002\right.$, $\left.P_{T G}=0.002.\right]$, and pineapple vinegar $\left[P_{A L T}=0.002\right.$, $P_{A L P}=0.003, \quad P_{A S T}=0.002, \quad P_{T G}=0.006$ significantly restored the concentrations of these enzymes to almost their normal levels. The treatments were dose-dependent (Table 1), the higher dosages of the vinegar samples were able to reduce the serum marker enzymes more effectively than the lower dosages.

\section{Liver antioxidant and NO determinations}

The antioxidant activities in paracetamol-intoxicated mice were evaluated by several antioxidant assays, comprising GSH, SOD, FRAP, MDA, and NO assays (Table 2). The increases in antioxidant strength (GSH, SOD, and FRAP) led to depletion of the MDA and NO levels. Both high concentration pineapple vinegar and synthetic vinegar improved the GSH content $\left[P_{P H}=0.003, P_{S H}=0.013\right]$, SOD $\left[P_{P H}<0.001, P_{S H}=0.002.\right]$, and FRAP $\left[P_{P H}<0.001\right.$, $\left.P_{S H}=0.003\right]$, and reduced NO $\left[P_{P H}=0.002, P_{S H}=0.033\right]$ and MDA $\left[P_{P H}=0.002, P_{S H}=0.030\right]$ significantly, and the effects were dose-dependent. However, due to the differences in phenolic contents between the samples, high-dose pineapple vinegar provided better recovery in abolishing the effects of paracetamol-induced liver damage compared with the other treatments.

\section{Liver histopathology}

Histopathological assessments using liver sections were performed for all experimental groups by hematoxylin and eosin staining (Figure 1). In the paracetamol-induced hepatotoxicity group, microvesicular steatosis, and accumulation of fat in the liver were observed in the paracetamol-induced hepatotoxicity group. Treatments with silybin and high concentrations of synthetic vinegar and pineapple vinegar caused mild fatty changes in the hepatic parenchyma. The nucleus and cytoplasm of cells were well-shaped and no changes were observed in their structures (Figure 1A). In contrast, changes in the liver structure such as microvesicular steatosis (arrow), regeneration in the nucleus with clumping, increase in nuclear size, and ballooning were observed in the untreated control group given paracetamol (Figure 1B). Figures $1 C, D, E, F$, and $G$ show liver sections from the groups treated with silybin, high-dose synthetic vinegar, low-dose synthetic vinegar, high-dose pineapple vinegar, and low-dose pineapple vinegar, respectively. The recovery in the synthetic vinegar groups was much lower than that in the pineapple vinegar groups, with moderate recovery in the high-dose synthetic vinegar group. Normalization of hepatocytes into normal structures with significant reductions in microvesicular steatosis, ballooning, and hepatocyte necrosis were observed for both concentrations of pineapple vinegar.

\section{Quantitative PCR gene expression analyses for iNOS and $\mathrm{NF}-\mathrm{KB}$ in the liver}

The expression levels of the iNOS and NF- $k B$ genes in the liver were analyzed by quantitative PCR (Figure 2). Oral administration of both concentrations of pineapple vinegar significantly decreased the iNOS $\left[P_{P H}=0.003\right.$, $\left.P_{P L}=0.003\right]$ and NF-kB $\left[P_{P H}=0.003, P_{P L}=0.003\right]$ expression

Table 1 Serum biochemical parameters of different experimental groups on paracetamol (PCM) induced hepatotoxicity in mice

\begin{tabular}{lllll}
\hline Group $(\mathbf{n}=\mathbf{1 0})$ & ALT (U/L) & ALP (U/L) & AST (U/L) & Triglyceride (mmol/L) \\
\hline 1 & $61.23 \pm 5.57^{*}$ & $85.67 \pm 2.32^{*}$ & $145.20 \pm 15.15^{*}$ & $2.33 \pm 0.64^{*}$ \\
2 & $123.94 \pm 7.25$ & $104.44 \pm 2.31$ & $368.76 \pm 9.83$ & $3.44 \pm 0.56$ \\
3 & $72.44 \pm 8.23^{*}$ & $81.75 \pm 1.51^{*}$ & $250.46 \pm 11.14^{*}$ & $2.11 \pm 0.24^{*}$ \\
4 & $45.44 \pm 2.63^{*}$ & $85.83 \pm 2.55^{*}$ & $172.64 \pm 10.58^{*}$ & $2.53 \pm 1.11^{*}$ \\
5 & $76.53 \pm 4.15^{*}$ & $91.83 \pm 1.25^{*}$ & $235.96 \pm 13.19^{*}$ & $2.63 \pm 1.06^{*}$ \\
6 & $45.26 \pm 7.59^{*}$ & $75.75 \pm 1.77^{*}$ & $184.03 \pm 28.88^{*}$ & $1.99 \pm 0.46^{*}$ \\
7 & $74.31 \pm 7.35^{*}$ & $85.75 \pm 2.88^{*}$ & $239.33 \pm 28.24^{*}$ & $2.83 \pm 0.69^{*}$ \\
\hline
\end{tabular}

Values are expressed as mean \pm SD where *indicates that the values are significantly difference from paracetamol control group, $P<0.05$.

Group1: normal mice; group 2: paracetamol control (250 mg/kg PCM + PBS); group 3: positive control (250 mg/kg PCM + $50 \mathrm{mg} / \mathrm{kg}$ silybin); group 4: acetic acid control ( $250 \mathrm{mg} / \mathrm{kg}$ PCM $+2 \mathrm{~mL} / \mathrm{kg}$ synthetic vinegar; group 5: acetic acid control $(250 \mathrm{mg} / \mathrm{kg} \mathrm{PCM}+0.08 \mathrm{~mL} / \mathrm{kg}$ synthetic vinegar; group 6: $250 \mathrm{mg} / \mathrm{kg}$ $\mathrm{PCM}+2 \mathrm{~mL} / \mathrm{kg}$ pineapple vinegar; group 7: $250 \mathrm{mg} / \mathrm{kg} \mathrm{PCM}+0.08 \mathrm{~mL} / \mathrm{kg}$ pineapple vinegar. 
Table 2 Liver antioxidant and NO determination of different experimental groups on paracetamol (PCM) induced hepatotoxicity in mice

\begin{tabular}{|c|c|c|c|c|c|}
\hline $\begin{array}{l}\text { Group } \\
(n=10)\end{array}$ & GSH (nm GSH/mg protein) & SOD (U/mg protein) & FRAP ( $\mu \mathrm{M} \mathrm{Fe(II)/mg} \mathrm{protein)}$ & MDA (nM MDA/mg protein) & NO ( $\mu \mathrm{M} / \mathrm{mg}$ protein) \\
\hline 1 & $4.16 \pm 0.04^{*}$ & $122.18 \pm 1.09^{*}$ & $21.13 \pm 1.99^{*}$ & $1.53 \pm 0.28^{*}$ & $20.71 \pm 2.67^{*}$ \\
\hline 2 & $2.55 \pm 0.03$ & $41.50 \pm 1.38$ & $12.77 \pm 1.68$ & $5.14 \pm 0.10$ & $44.74 \pm 1.05$ \\
\hline 3 & $4.63 \pm 0.03^{*}$ & $145.47 \pm 2.87^{*}$ & $20.73 \pm 1.78^{*}$ & $1.63 \pm 0.21^{*}$ & $27.61 \pm 3.08^{*}$ \\
\hline 4 & $4.78 \pm 0.01^{*}$ & $125.33 \pm 1.65^{*}$ & $20.77 \pm 5.85^{*}$ & $1.65 \pm 0.24^{*}$ & $32.45 \pm 3.21^{*}$ \\
\hline 5 & $4.26 \pm 0.04^{*}$ & $84.99 \pm 2.53^{*}$ & $14.78 \pm 3.30$ & $2.50 \pm 0.57^{*}$ & $36.68 \pm 6.20$ \\
\hline 6 & $7.57 \pm 0.12^{*}$ & $203.53 \pm 3.64^{*}$ & $26.02 \pm 2.10^{*}$ & $1.51 \pm 0.01^{*}$ & $19.74 \pm 0.87^{*}$ \\
\hline 7 & $5.54 \pm 0.03^{*}$ & $139.55 \pm 1.52^{*}$ & $20.87 \pm 2.65^{*}$ & $1.56 \pm 0.09^{*}$ & $31.66 \pm 4.87^{*}$ \\
\hline
\end{tabular}

Values are expressed as mean \pm SD where * indicates that the values are significantly difference from paracetamol control group, $P<0.05$.

Group1: normal mice; group 2: paracetamol control (250 mg/kg PCM + PBS); group 3: positive control (250 mg/kg PCM + $50 \mathrm{mg} / \mathrm{kg}$ silybin); group 4: acetic acid control ( $250 \mathrm{mg} / \mathrm{kg}$ PCM $+2 \mathrm{~mL} / \mathrm{kg}$ synthetic vinegar; group 5: acetic acid control $(250 \mathrm{mg} / \mathrm{kg} \mathrm{PCM}+0.08 \mathrm{~mL} / \mathrm{kg}$ synthetic vinegar; group 6: $250 \mathrm{mg} / \mathrm{kg}$ $\mathrm{PCM}+2 \mathrm{~mL} / \mathrm{kg}$ pineapple vinegar; group $7: 250 \mathrm{mg} / \mathrm{kg} \mathrm{PCM}+0.08 \mathrm{~mL} / \mathrm{kg}$ pineapple vinegar.

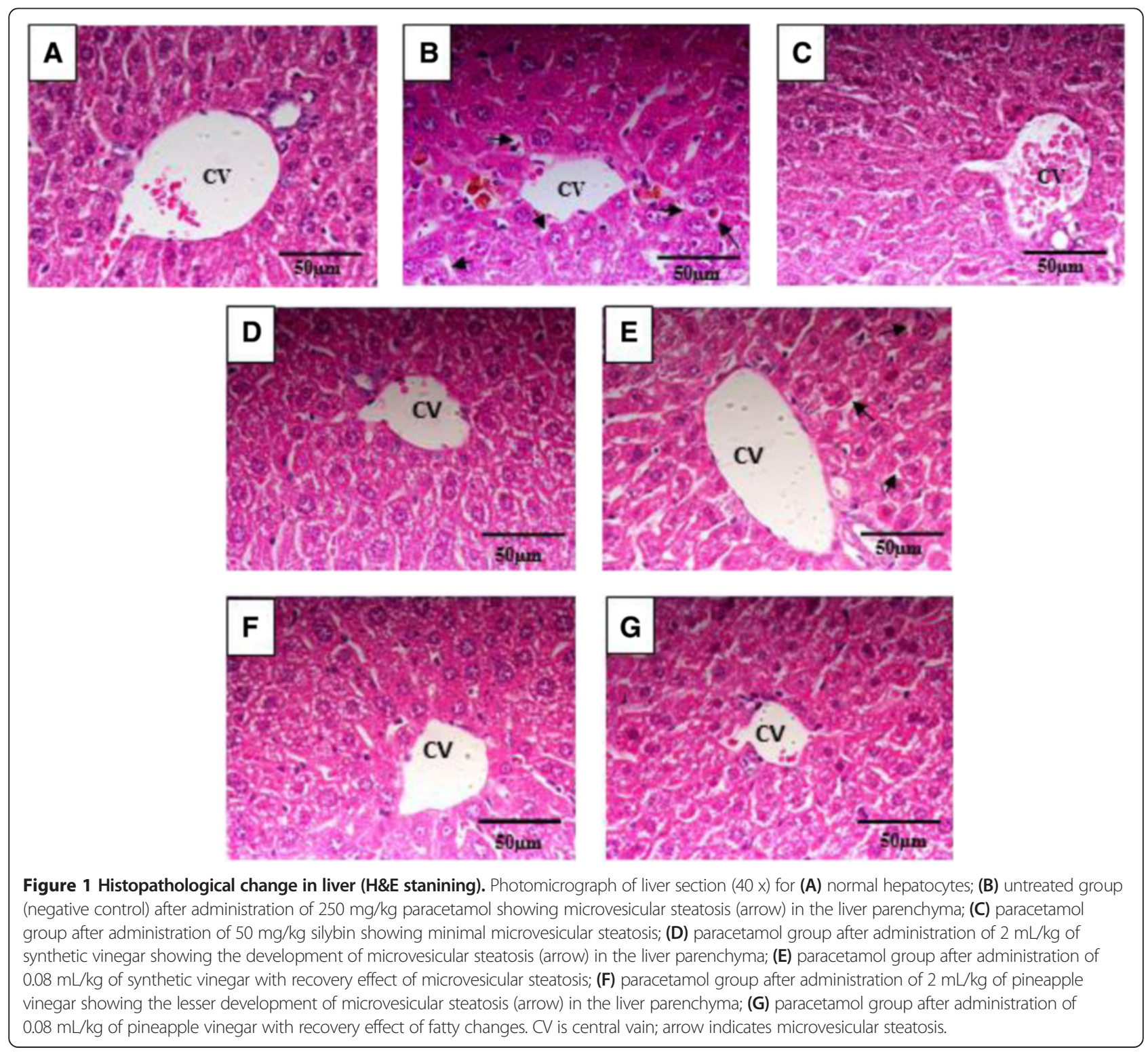




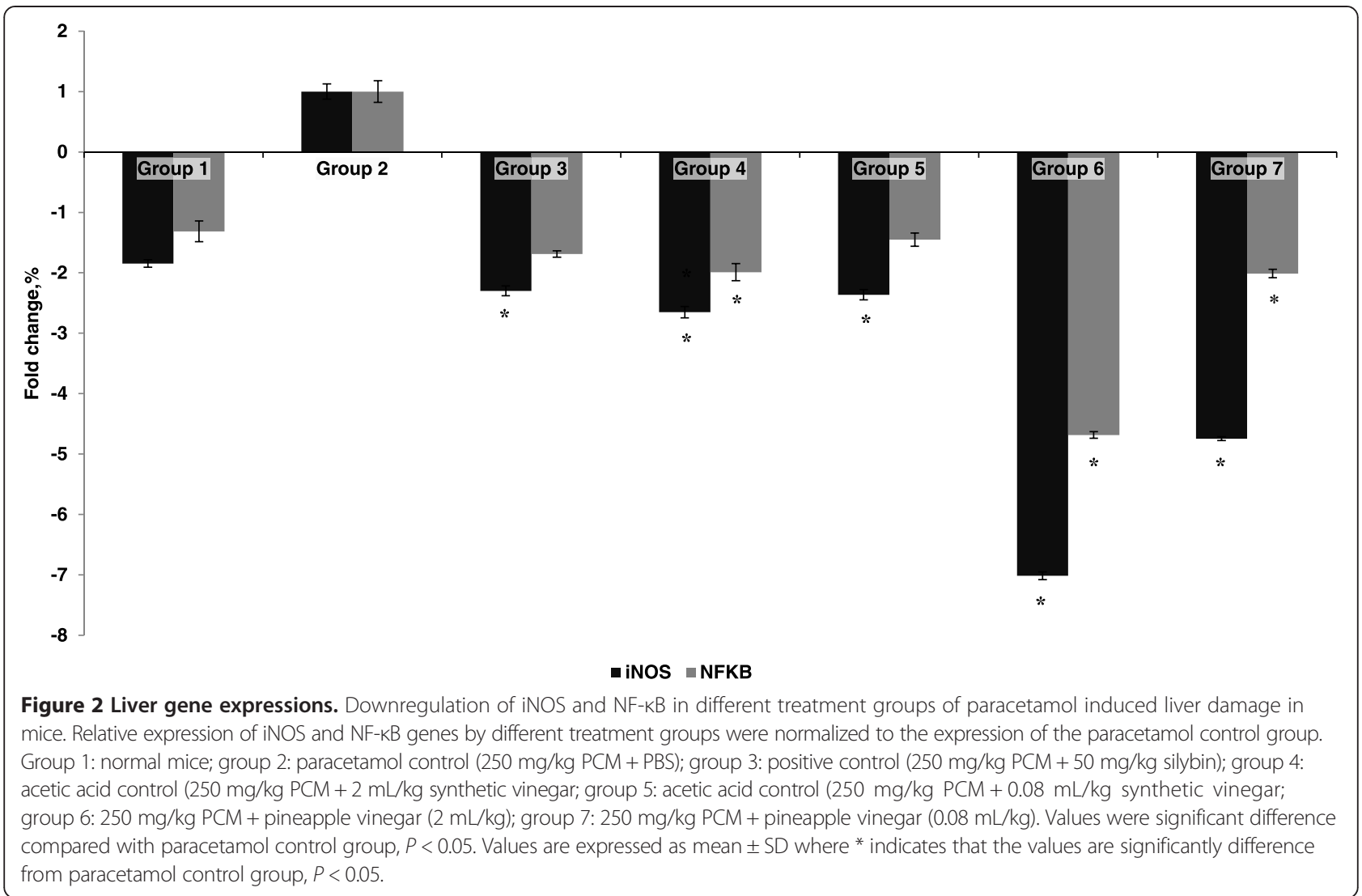

levels compared with the paracetamol control group, and the greatest downregulation of both genes was observed in the high-dose pineapple vinegar group.

\section{Western blot analysis of cytochrome P450 levels in the liver}

Figure 3 shows the cytochrome P450 2E1 protein expression levels in the liver tissues of the different experimental groups. The P450 protein expression level was significantly decreased by $62 \%$ in the high-dose pineapple vinegar group compared with the paracetamol control group. Moderate decreases were noted in the other treatment groups (silybin, high-dose synthetic vinegar, low-dose synthetic vinegar, and low-dose pineapple vinegar) with no significant differences between the groups.

\section{Total phenolic and soluble phenolic acid contents in} pineapple vinegar

From the calorimetric assay results, the total phenolic content in pineapple vinegar was $169.67 \pm 0.05-\mu \mathrm{g}$ $\mathrm{GAE} / \mathrm{mL}$, while synthetic vinegar had no phenolic content. HPLC was carried out to confirm these results and further investigate the phenolic acid derivatives in both samples. From the HPLC results, gallic acid $(862.61 \pm 4.38 \mu \mathrm{g} / \mathrm{mL})$ was the main component of the phenolic compounds in pineapple vinegar followed by caffeic $(218.91 \pm 3.24 \mu \mathrm{g} / \mathrm{mL})$ and benzoic acid $(177.90 \pm 14.02 \mu \mathrm{g} / \mathrm{mL})$, while no phenolic compounds were detected in synthetic vinegar. The total phenolic contents and phenolic acid derivatives are shown in Table 3.

\section{In vitro evaluation of antioxidant activities of vinegar samples}

The antioxidant strength of pineapple vinegar was tested by FRAP and DPPH radical-scavenging activity. The inhibitory concentration $\left(\mathrm{IC}_{50}\right)$ values for the radicalscavenging activities of pineapple vinegar in this study were $69.28 \pm 0.18 \%$ and $357.72 \pm 0.07-\mu \mathrm{g} \mathrm{TE} / \mathrm{mL}$ for the FRAP assay. No values for FRAP and no $\mathrm{IC}_{50}$ values for radical-scavenging activities were found in synthetic vinegar.

\section{Discussion}

Overdose of paracetamol causes liver inflammation, which results in increased TG levels due to impaired fat metabolism and fatty changes [30]. Change or loss of the structural integrity of hepatocytes caused residing enzymes, such as ALT, ALP, and AST, to leak out and increase their concentrations in the blood [31]. Decreases in TG levels and these enzymes showed hepatoprotective effects and restored the hepatocyte structure [32]. Acetic 


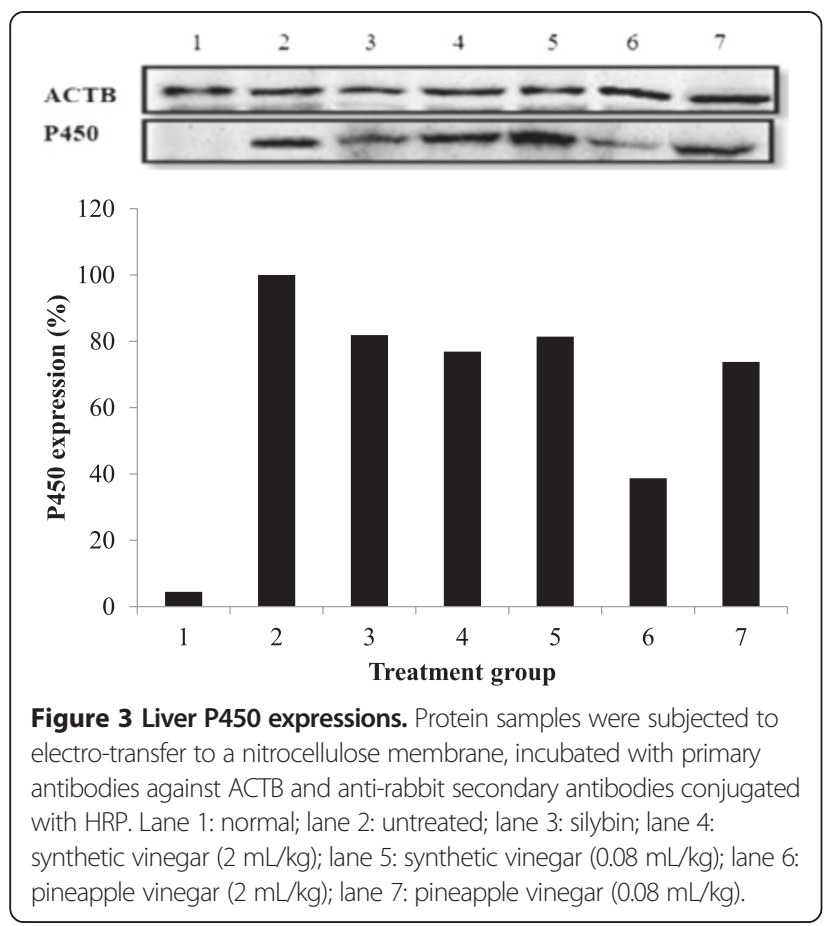

acid improved fatty acid oxidation in the liver [33,34], thereby lowering TG levels in blood and reducing microvesicular steatosis development in liver tissues. Additional mechanisms through active constituents such as flavonoids and silybin restored these enzymes to protect liver cells [17] by preventing leakage of the intracellular enzymes through repair and stabilization of the hepatocyte membrane [35]. Reduced microvesicular steatosis and ballooning were observed in liver tissues in all treatment groups. The present results demonstrated that the recovery in mice treated with pineapple vinegar

Table 3 Total phenolic, soluble phenolic acids content, DPPH and FRAP of pineapple vinegar

\begin{tabular}{lll}
\hline & $\begin{array}{l}\text { Pineapple } \\
\text { vinegar }\end{array}$ & $\begin{array}{l}\text { Synthetic } \\
\text { vinegar }\end{array}$ \\
\hline Total phenolic content $(\mu \mathrm{g} G A E / \mathrm{mL})$ & $169.67 \pm 0.05$ & $\mathrm{ND}$ \\
Phenolic acid derivatives $(\mathrm{HPLC})$ : & & \\
Gallic acid $(\mu \mathrm{g} / \mathrm{mL})$ & $862.61 \pm 4.38$ & $\mathrm{ND}$ \\
Caffeic acid $(\mu \mathrm{g} / \mathrm{mL})$ & $218.91 \pm 3.24$ & $\mathrm{ND}$ \\
Benzoic acid $(\mu \mathrm{g} / \mathrm{mL})$ & $177.90 \pm 14.02$ & $\mathrm{ND}$ \\
Sinapic acid $(\mu \mathrm{g} / \mathrm{mL})$ & $154.28 \pm 4.09$ & $\mathrm{ND}$ \\
Vanillic acid $(\mu \mathrm{g} / \mathrm{mL})$ & $117.35 \pm 3.99$ & $\mathrm{ND}$ \\
$\beta$-hydroxybenzoic $(\mu \mathrm{g} / \mathrm{mL})$ & $83.99 \pm 1.15$ & $\mathrm{ND}$ \\
Protocatechuic acid $(\mu \mathrm{g} / \mathrm{mL})$ & $78.75 \pm 1.70$ & $\mathrm{ND}$ \\
Syringic acid $(\mu \mathrm{g} / \mathrm{mL})$ & $55.46 \pm 9.51$ & $\mathrm{ND}$ \\
DPPH $(\%)$ & $69.28 \pm 0.18$ & $\mathrm{ND}$ \\
FRAP $(\mu \mathrm{g}$ TE $/ \mathrm{mL})$ & $357.72 \pm 0.07$ & $\mathrm{ND}$ \\
\hline
\end{tabular}

$\mathrm{ND}$ indicates not detected. was better than that in the mice treated with synthetic vinegar due to its antioxidant strength.

Phenolic compounds are secondary metabolites in plants and plant products that contribute to their antioxidant activities [36]. Improved GSH levels in the liver reversed the effects of paracetamol-induced liver injury through conjugation between GSH and NAPQI [37]. The total reducing and antioxidant capacities of the vinegar samples decreased NO and lipid peroxidation, which resulted in decreased MDA levels in the liver [38]. From the antioxidant results shown in Table 2, both pineapple vinegar and synthetic vinegar increased the antioxidant levels in liver homogenates, although pineapple vinegar acted as a more effective hepatoprotectant than synthetic vinegar. The acetic acid contents in the samples may also contribute to the antioxidant activities in the liver and restoration of liver marker enzymes. To date, there have been no reports on the possible mechanisms of acetic acid in treating hepatotoxicity. However, because of the capability of acetic acid to reduce the fatty changes in hepatocytes, it might assist in the restoration and preservation of the antioxidant potential of liver cells [33].

Western blot and quantitative PCR analyses were performed to assess gene and protein expressions. NF- $\mathrm{kB}$, one of the inflammatory reactants, is a transcriptional factor that is activated in most cell types as a response to foreign pathogens or general stress insults [39]. Activation of NF- $\mathrm{kB}$ upregulates the expressions of inflammatory genes such as iNOS [40]. The present results demonstrated that a high concentration of pineapple vinegar downregulated the expression of iNOS. This finding was supported by the reduction in the NO levels, indicating that the high dose of pineapple vinegar significantly reduced paracetamol-induced liver inflammation.

Any sample or compound that induces cytochrome P450 2E1 can induce hepatotoxicity [41,42], including paracetamol [43], while improved levels of GSH and antioxidants reduce the levels of cytochrome P450 2E1 [44]. Under oxidative stress, NO induced detoxification by increasing the levels of SOD and GSH [45], and restored balance to the liver cells by conjugation with the reactive metabolite [46]. As shown in Figure 3, the significant down-regulation of P450 observed in the mice treated with the high dose of pineapple vinegar might be attributed to the increased GSH and antioxidant levels in the samples evaluated by western blotting.

Pineapple is a good source of antioxidants [47]. Antioxidant strength is measured by both phenolic and non-phenolic compounds, as they reverse free radical activities by decomposing peroxides and unpaired oxygen molecules, and adsorbing and neutralizing the free radicals to render them harmless to the body [48]. The fermentation process broke down undesirable compounds and increased the contents of some phenolic and non-phenolic 
compounds $[49,50]$. From both the in vitro and in vivo data in the present study, pineapple vinegar possessed high antioxidant activity compared with synthetic vinegar. As shown in Table 3, HPLC identified gallic acid as the active compound in pineapple vinegar, followed by caffeic, benzoic, sinapic, vanillic, $\beta$-hydroxybenzoic, protocatechuic, and syringic acids.

Gallic acid has been shown to suppress the activation of cytochrome P450 through its antioxidant and scavenging activities [51]. Furthermore, vanillic and syringic acids were found to suppress oxidative stress and reduce inflammation and fibrogenesis in $\mathrm{CCl}_{4}$-induced liver damage in BALB/c mice [52]. Sinapic acid significantly reduced lipid peroxidation and suppressed the activation of NF- $\mathrm{KB}$ in dimethylnitrosamine-induced fibrosis in rats [53]. Moreover, caffeic acid increased the GSH and catalase levels and reduced MDA lipid peroxidation in liver homogenates [54]. As shown in Table 3, all of these phenolic acid derivatives were major components of the phenolic compounds in pineapple vinegar. The hepatoprotective effects of pineapple vinegar may be contributed by these phenolic acid derivatives through their antioxidant strengths and scavenging activities, to restore the serum marker enzymes in the liver, repair the hepatocyte structure, and suppress the activation of cytochrome P450 through the downregulation of iNOS and NF-kB.

\section{Conclusions}

Oral administration of pineapple vinegar at 0.08 and $2 \mathrm{~mL} / \mathrm{kg}$ BW reduced serum enzyme biomarker levels, restored liver antioxidant levels, reduced inflammatory factor expressions, and down-regulated liver cytochrome P450 protein expression in paracetamol-induced liver damage in mice.

\begin{abstract}
Abbreviation
ACTB: $\beta$-actin; ALP: Alkaline phosphatase; ALT: Alanine aminotransferase; AST: Aspartate aminotransferase; $\mathrm{CCL}_{4}$ : Carbon tetrachloride; DMN: dimethyl nitrosamine; DPPH: 2,2-diphenyl-2-picrylhydrazyl; FRAP: Ferric reduction ability plasma; GAPDH: Glyceraldehyde 3-phosphate dehydrogenase; GSH: Glutathione reductase; HPLC: High-performance liquid chromatography; HPRT: Hypoxanthine phosphoribosyltransferase; $\mathrm{I}_{50}$ : Inhibitory concentration; iNOS: Inducible nitric oxide synthase; MDA: Melonaldehyde; NAPQI: $\mathrm{N}$-acetyl-p-benzoquinoneimine; NF-kB: Nuclear factor kappa-light-chain-enhancer of activated B cells; NO: Nitric oxide; qRT-PCR: Quantitative reverse transcriptase polymerase chain reaction; SDS-PAGE: Sodium dodecyl sulfate polyacrylamide gel electrophoresis; SOD: Superoxide dismutase; TG: Triglycride; TPTZ: 2,4,6-Tri(2-pyridyl)-s-triazine.
\end{abstract}

\section{Competing interest}

The authors declare that they have no competing interests.

\section{Authors' contribution}

NEM, SKY, BKB, HMY, WYH, SWT, KLL, AJ, SAS, KL, NMANAR and NBA, conceived and designed the experiments. NEM, KLL and AJ analyzed the data. NEM wrote the manuscript. SKY and NBA reviewed the manuscript. All authors read and approved the final manuscript.

\section{Acknowledgement}

This study was supported by the grant from Pembangunan RMK10, MARDI. The authors would also like to thank Professor Dr. Tan Soon Guan and Mr. Muhammad Firdaus Romli for proofreading.

\section{Author details}

${ }^{1}$ Department of Cell and Molecular Biology, Faculty of Biotechnology and Biomolecular Science, Universiti Putra Malaysia, Serdang, Selangor 43400, Malaysia. ${ }^{2}$ Institute of Bioscience, Universiti Putra Malaysia, Serdang, Selangor 43400, Malaysia. ${ }^{3}$ Faculty of Medicine and Health Sciences, Universiti Tunku Abdul Rahman, Sungai Long Campus, Jalan Sungai Long, Bandar Sungai Long, Cheras, Kajang 43000, Selangor, Malaysia. ${ }^{4}$ School of Biomedical Sciences, The University of Nottingham Malaysia Campus, Jalan Broga, 43500, Semenyih, Selangor 43400, Malaysia. ${ }^{5}$ Biotechnology Research Centre, Malaysian Agricultural Research and Development Institute (MARDI), Serdang, Selangor 43400, Malaysia.

Received: 3 April 2014 Accepted: 23 January 2015

Published online: 13 February 2015

\section{References}

1. Frayn KN, Arner P, Yki-Järvinen H. Fatty acid metabolism in adipose tissue, muscle and liver in health and disease. Essays Biochem. 2006;42:89-103.

2. Miller $\mathrm{LL}$, Bly $\mathrm{CG}$, Watson ML, Bale WF. The dominant role of the liver in plasma protein synthesis,a direct study of the isolated perfused rat liver with the aid of lysine- $\epsilon-C 14$. J Exp Med. 1951;94:431-53.

3. Farrar Jr WE, Corwin LM. The essential role of the liver in detoxification of endotoxin. Ann N Y Acad Sci. 1966;133:668-84.

4. Poli G. Liver damage due to free radicals. Oxford J Med. 1993;49:604-20.

5. Prescott LF. Paracetamol overdosage. Drugs. 1983;25:290-314.

6. Bhanwra S, Singh J, Khosla P. Effect of Azadirachta indica (neem) leaf aqueous extracton paracetamol-induced liver damage in rats. Indian J Physiol Pharmacol. 2000;44:64-8.

7. Bullon P, Newman HN, Battino M. Obesity, diabetes mellitus, atherosclerosis and chronic periodontitis: a shared pathology via oxidative stress and mitochondrial dysfunction? Periodontology. 2014;64:139-53.

8. Pinsirodom P, Rungcharoen J, Liumminful A. Quality of commercial wine vinegars evaluated on the basis of total polyphenol content and antioxidant properties. Asian J Food Agro-Industry. 2010;3:389-97.

9. Seki T, Morimura S, Tabata S, Tang Y, Shigematsu T, Kida K. Antioxidant activity of vinegar produced from distilled residues of the japanese liquour shochu. J Agric Food Chem. 2008;56:3785-90.

10. Guerrero EDA, Mej'Ias RC, Marín RN, Lovillo MP, Barroso CG. A new FT-IRmethod combined with multivariate analysis for the classification of vinegars from different raw materials and production processes. J Sci Food Agric. 2010;90:712-8.

11. Budak NH, Doguc DK, M. Savas C, Seydim AC, Tas TK, Ciris Ml, et al. Effects of apple cider vinegars produced with different techniques on blood lipids in high-cholesterol-fed rats. J Agric Food Chem. 2011;59:6638-44.

12. Gu X, Zhao H-L, Sui Y, Guan J, Chan JCN, Tong PCY. White rice vinegar improves pancreatic beta-cell function and fatty liver in streptozotocin-induced diabetic rats. Acta Diabetol. 2012;49:185-91.

13. Kondo S, Tayama K, Tsukamoto Y, Ikeda K, Yamori Y. Antihypertensive effects of acetic acid and vinegar on spontaneously hypertensive rats. Biosci Biotechnol Biochem. 2001;65:2690-4.

14. Shimoji Y, Kohno H, Nanda K, Nishikawa Y, Ohigashi H, Uenakai K, et al. Extract of kurosu, a vinegar from unpolished rice, inhibits azoxymethane-induced colon carcinogenesis in male F344 rats. Nutr Cancer. 2004:49:170-3.

15. Fan J, Zhang Y, Chang X, Zhang B, Jiang D, Saito M, et al. Antithrombotic and fibrinolytic activities of methanolic extract of aged sorghum vinegar. J Agric Food Chem. 2009;57:8683-7.

16. Pinto TMS, Neves ACC, Leao MVP, Jorge AOC. Vinegar as antimicrobial agent for control of Candida spp. in complete denture wearers. J Appl Oral Sci. 2008;16:385-90.

17. Xiang J, Zhu W, Li Z, Ling S. Effect of juice and fermented vinegar from Hovenia dulcis peduncles on chronically alcohol-induced liver damage in mice. Food Funct. 2012;3:628-34.

18. Tochi BN, Wang Z, Xu S-Y, Zhang W. Therapeutic application of pineapple protease(bromelain): a review. Pak J Nutr. 2008;7:513-20.

19. Mhatre M, Tilak-Jain J, De S, Devasagayam TPA. Evaluation of the antioxidant activity of non-transformed and transformed pineapple: a comparative study. Food Chem Toxicol. 2009;47:2696-702. 
20. Jacques DT, Marc KT, Marius A. Biochemical effectiveness in liver detoxication of fresh pineapple (Ananas comosus) with the wistar rats, previously intoxicated by Doliprane. J Cell AnimBiol. 2008;2:031-5.

21. Dougnon TJ, Kpodekon TM, Ahissou H, Gbenou J, Loko F, Laleye L. Protective effect of stem pineapple on Wistar rat poisoning with paracetamol. Int J Biol Chem Sci. 2009;3:688-93.

22. Olaleyea MT, Rocha BTJ. Acetaminophen-induced liver damage in mice: effects of some medicinal plants on the oxidative defense system. Exp Toxicol Pathol. 2008;59:319-27.

23. Moon Y-J, Choi D-S, Oh S-H, Song Y-S, Cha Y-S. Effects of persimmon-vinegar on lipid and carnitine profiles in mice. Food Sci Biotechnol. 2010;19:343-8.

24. Yusof HM, Ali N, Yeap SK, Ho WY, Beh BK, Koh SP, et al. Hepatoprotective effect of fermented soybean (nutrient enriched soybean tempeh) against alcohol-induced liver damage in mice. Evid Based Complement Alternat Med. 2013;2013:1-9.

25. Y-h C, Yang C-m, Chang S-p, Hu M-I. C/EBP beta and C/EBP delta expression is elevated in the early phase of ethanol-induced hepatosteatosis in mice. Acta Pharmacol Sin. 2009;30:1138-43.

26. Lee KJ, You HJ, Park SJ, Kim YS, Chung YC, Jeong TC, et al. Hepatoprotective effects of Platycodon grandiflorum on acetaminophen-induced liver damage in mice. Cancer Lett. 2001:174:73-81.

27. Ho WY, Yeap SK, Ho CL, Rahim RA, Alitheen NB. Hepatoprotective activity of Elephantopus scaber on alcohol-induced liver damage in mice. Evid Based Complement Alternat Med. 2012;2012:1-8.

28. Nagavani V, Rao TR. Evaluation of antioxidant potential and identification of polyphenolsby RP-HPLC in Michelia champaca flowers. Adv Biol Res. 2010;4:159-68.

29. Thaipong K, Boonprakob U, Crosby K, Cisneros-Zevallos L, Byrne DH. Comparison of ABTS, DPPH, FRAP, and ORAC assays for estimating antioxidant activity from guava fruit extracts. J Food Compos Anal. 2006;19:669-75.

30. Basu S, Haldar N, Bhattacharya Sanji BS, Biswas M. Hepatoprotective activity of Litchi chinensis leaves against paracetamol-induced liver damage in rats. Am-Eur J Sci Res. 2012;7:77-81.

31. Ozer J, Ratner M, Shaw M, Bailey W, Schomaker S. The current state of serum biomarkers of hepatotoxicity. Toxicology. 2008;245:194-205.

32. Kang H, Koppula S. Hepatoprotective effect of Houttuynia cordata thunb extract against carbon tetrachloride-induced hepatic damage in mice. Indian J Pharm Sci. 2014;76:267-73.

33. Kim JY, Ok E, Kim YJ, Choi K-S, Kwon O. Oxidation of fatty acid may be enhanced by a combination of pomegranate fruit phytochemicals and acetic acid in HepG2 cells. Nutr Res Pract. 2013;7:153-9.

34. Kondo T, Kishi M, Fushimi T, Kaga T. Acetic acid upregulates the expression of genes for fatty acid oxidation enzymes in liver to suppress body fat accumulation. J Agric Food Chem. 2009:57:5982-6.

35. Vitaglione P, Morisco F, Caporaso N, Fogliano V. Dietary antioxidant compounds and liver health. Crit Rev Food Sci Nutr. 2004;44:575-86

36. Jeong C-H, Choi GN, Kim JH, Kwak JH, Kang S-T, Choi S-G, et al. In vitro antioxidant properties and phenolic composition of korean commercial vinegars. Food Sci Biotechnol. 2009;18:1258-a1262.

37. Cheedella HK, Alluri R, Ghanta KM. Hepatoprotective and antioxidant effect of Ecbolium viride(Forssk.) Alston roots against paracetamol-induced hepatotoxicity in albino wistar rats. J Pharm Res. 2013;7:496-501.

38. Sunil C, Duraipandiyan V, lgnacimuthu S, Al-Dhabib NA. Antioxidant, free radical scavenging and liver protective effects of friedelin isolated from Azima tetracantha Lam. leaves. Food Chem. 2013;139:860-5.

39. Arias-Salvatierra D, Silbergeld EK, Acosta-Saavedra LC, Calderon-Aranda ES. Role of nitric oxide produced by iNOS through NF-KB pathway in migration of cerebellar granule neurons induced by lipopolysaccharide. Cell Signal. 2011;23:425-35.

40. Zamora R, Vodovotz $Y$, Billiar TR. Inducible nitric oxide synthase and inflammatory diseases. Mol Med. 2000;6:347-73.

41. Ha K-T, Yoon S-J, Choi D-Y, Kim D-W, Kim J-K, Kim C-H. Protective effect of Lycium chinense fruit on carbon tetrachloride-induced hepatotoxicity. J Ethnopharmacol. 2005;96:529-35.

42. Lee KJ, Woo E-R, Choi CY, Shin DW, Lee DG, You HJ, et al. Protective effect of acteoside on carbon tetrachloride-induced hepatotoxicity. Life Sci. 2004; $74: 1051-64$

43. Hwang J, Chang Y-H, Park JH, Kim SY, Chung H, Shim E, et al. Dietary saturated and monounsaturated fats protect against acute acetaminophen hepatotoxicity by altering fatty acid composition of liver microsomal membrane in rats. Lipids Health Dis. 2011;10:1-8.
44. Jeong SC, Kim SM, Jeong YT, Song CH. Hepatoprotective effect of water extract from Chrysanthemum indicum L.flower. Chin Med. 2013:8:1-8.

45. El-Beshbishy HA. Hepatoprotective effect of green tea (Camellia sinensis) extract against tamoxifen-induced liver injury in rats. J Biochem Mol Biol. 2005:38:563

46. Zhao J, Chen H, Li Y. Protective effect of bicyclol on acute alcohol-induced liver injury in mice. Eur J Pharmacol. 2008;586:322-31.

47. Hossaina MA, Rahman SMM. Total phenolics, flavonoids and antioxidant activity of tropical fruit pineapple. Food Res Int. 2011;44:672-6.

48. Martinez MC, Afonso SG, Buzaleh AM. Batlle A: Protective action of antioxidants on hepatic damage induced by griseofulvin. Sci World J. 2014;2014:1-8

49. Hunaefia D, Akumo DN, Smetanska I. Effect of fermentation on antioxidant properties of red cabbages. Food Biotechnol. 2013;27:66-85

50. Martin LJ, Matar C. Increase of antioxidant capacity of the lowbush blueberry (Vaccinium angustifolium) during fermentation by a novel bacterium from the fruit microflora. J Sci Food Agric. 2005;85:1477-84.

51. Tung Y-T, Wu J-H, Huang C-C, Peng H-C, Chen Y-L, Yang S-C, et al. Protective effect of Acacia confusa bark extract and its active compound gallic acid against carbon tetrachloride-induced chronic liver injury in rats. Food Chem Toxicol. 2009:47:1385-92.

52. Itoh $\mathrm{A}$, Isoda $\mathrm{K}$, Kondoh $\mathrm{M}$, Kawase $\mathrm{M}$, Watari $\mathrm{A}$, Kobayashi $\mathrm{M}$, et al. Hepatoprotective effect of syringic acid and vanillic acid on CCl4-induced liver injury. Biol Pharm Bull. 2010;33:983-7.

53. Shin D-S, Kim KW, Chung HY, Yoon S, Moon J-O. Effect of sinapic acid against dimethylnitrosamine-induced hepatic fibrosis in rats. Arch Pharm Res. 2013;36:608-18.

54. Yanga S-Y, Honga C-O, b GPL, Kimc C-T, Lee K-W. The hepatoprotection of caffeic acid and rosmarinic acid, major compounds of Perilla frutescens, against t-BHP-induced oxidative liver damage. Food Chem Toxicol. 2013:55:92-9.

\section{Submit your next manuscript to BioMed Central and take full advantage of:}

- Convenient online submission

- Thorough peer review

- No space constraints or color figure charges

- Immediate publication on acceptance

- Inclusion in PubMed, CAS, Scopus and Google Scholar

- Research which is freely available for redistribution

Submit your manuscript at www.biomedcentral.com/submit 